\title{
Telemonitoring for Seniors with Chronic Heart Failure: Patient Self-Care, Empowerment, and Adoption Factors
}

\author{
Mirou Jaana, Ph.D. \\ University of Ottawa \\ jaana@telfer.uottawa.ca \\ Haitham Tamim, Ph.D. \\ Algonquin College \\ haitham.m.tamim@gmail.com \\ Heather Sherrard, M.H.A. \\ The University of Ottawa Heart Institute \\ hsherrard@toh.ca \\ Guy Paré, Ph.D. \\ HEC Montreal \\ guy.pare@hec.ca
}

\begin{abstract}
Telemonitoring (TM) represents a promising technology for the management of chronic diseases. It is of particular relevance to senior patients with heart failure (HF) condition. This study employs a longitudinal design, and involves three surveys of elderly HF patients $(n=23)$ administered one week, three months, and six months after system adoption. The main constructs were assessed based on existing validated scales. The results show that senior patients perceived value in using TM, did not expect the technology to be difficult to use, and did not encounter barriers to adoption. The analysis of impacts on selfcare revealed significant positive effects of TM on the confidence of senior patients in their self-care ability to evaluate their symptoms, address them, and evaluate the effectiveness of the measures they take. Significant positive effects were also observed on two measures of treatment implementation. TM may be leveraged to improve senior patients' self-care skills, which will benefit their health condition.
\end{abstract}

\section{Introduction}

Population aging represents a phenomenon that is observed worldwide. The proportion of people over 60 years of age has steadily increased to around $8 \%$ in 2010 , and is expected to triple and reach 2 billion persons by 2050 [2,35]. This situation presents significant challenges in relation to health care and social support, especially with potential support ratios (i.e. number of people 15-64 years old per one person $65+$ years) decreasing at alarming rates worldwide [35]. The increasing prevalence of chronic diseases, which have become the leading cause of death globally, is further adding to the complexity of the situation and creating a social and economic burden on patients and the society as a whole $[41,42]$.

Heart Failure (HF) represents a major lifethreatening chronic condition that characterizes the final stage of most types of heart disease, and is becoming increasingly prevalent around the world. More than 5.8 million people in the United States (US) and 23 million people worldwide suffer from HF [4], and the prevalence of this condition is high among elderly who usually account for $80 \%$ of hospitalizations and $90 \%$ of HF-related deaths [20]. In general, HF is responsible for one out of eight deaths in the US [4], and it represents a significant economic burden in developed countries, often accounting for $1 \%$ to $2 \%$ of healthcare expenditures [20].

HF management programs aim to improve patient outcomes through structured follow-up, patient education, symptoms monitoring, medications optimization, psychosocial support, and improving patients' access to care, in order to prevent exacerbations and costly hospitalizations [25]. The Canadian Cardiovascular Society recommends having multidisciplinary Disease Management Programs to improve quality and cost-effectiveness of care for chronic conditions. For HF specifically, these programs include HF clinics, home care, and telemonitoring [12]. 


\section{Proceedings of the $50^{\text {th }}$ Hawaii International Conference on System Sciences - 2017}

Telemonitoring (TM) refers to remote, noninvasive patient monitoring [19], which involves automated transmission of data from a patient's residence to a respective health care setting [28]. It employs telecommunication tools to transmit physiological or clinical data from a home setting to a health care center responsible for providing ongoing follow-up and treatment [17]. Hence, it supports effective management of patients [14] and allows early detection of deterioration in patients' conditions and timely intervention, which can prevent death and hospitalization [17]. Despite its benefits to a broad range of patients (e.g., [13,14,15]), TM may be particularly useful for elderly patients, especially for patients living in remote areas or housebound [19].

In a recent overview of systematic reviews on TM and HF, Kitsiou et al [17] recommended that future research assess the process by which TM works, investigate whether effectiveness varies between different patient groups, and identify optimal strategies for its success. This is especially important given the reported variation in compliance when using TM [29], and the particularities of elderly patients' that may influence their use of this technology. This study addresses some of these recommendations for a unique group of patients by: 1) examining the impact of this patient management approach on patient empowerment and self-care for senior patients with chronic HF; and 2) exploring the adoption factors, at the social and behavioral level, for elderly patients living at home and in the context of retirement homes.

\section{Literature Review}

Prior research in the area of TM has focused on the impacts of this patient management approach, mostly in relation to symptoms, mortality, and the utilization of services $[17,18,23]$. Yet, limited evidence exists on the actual effects of TM on patients' behaviors, especially patient empowerment and selfcare, with the exception of general discussion on patients' acceptability and attitude towards the technology. This is especially important in the context of elderly patients with $\mathrm{HF}$, who often face challenges engaging in self-care practices, and should be studied as a separate cohort [43]. In addition, no previous research has explored in details the behavioral and contextual factors related to TM adoption by seniors.

Patient empowerment and self-care represent important concepts that have been shaping global healthcare policies $[9,10]$. They have been broadly discussed in the TM literature, but prior studies have not investigated them in-depth, nor in relation to senior patients. Patient empowerment is a difficult concept to define, which manifests itself in patients who succeeded in regaining control over their condition $[5,6]$. It is an indication of a patient's ability to cope with an illness and his/her self-efficacy in managing this illness [5]. Bulsara et al [5] conducted an extensive literature review on patient empowerment and developed a measure that separately assesses this construct in relation to chronic illnesses. Their measure extends beyond the emotional state and examines the extent to which patients take control over their condition through various coping strategies.

Self-care refers to the decision making process that involves the choice of behaviors, which can maintain physical stability (i.e. "self-maintenance") and respond to symptoms when they happen (i.e. "selfcare management") [32]. Previous TM studies have discussed TM as facilitating self-care among general patient populations [31]. Nevertheless, most of the TM studies discussed self-care in general, and did not report evidence on the effectiveness of TM on self-care behavior [33]. Riley et al [33] conducted interviews with HF patients and reported that the majority of them developed self-care skills over a period of 12 months. Boyne et al. [3] also investigated the effects of TM on knowledge, self-care, self-efficacy, and adherence for $\mathrm{HF}$ patients, and reported that TM improved self-care abilities and self-efficacy although baseline differences were found for self-care in favor of the intervention group (TM). In a literature review on the impact of telehealth on self-management for HF, Radhakrishnan and Jacelon [31] called for future studies, with improved data collection procedures and designs, to examine the effect of telehealth on self-care [31].

Our literature review reveals that very few studies have investigated the adoption of TM by elderly or chronically ill people. A survey of 254 chronic patients by Peeters et al [30] showed that perceived characteristics of home telecare solutions, namely, relative advantage, compatibility, complexity and observability, have a significant effect on system adoption. They further observed that telehomecare acceptance is higher when the patient lives alone and when there are fixed daily contacts with the telecare system. As another example, van Offenbeek et al [36] developed a conceptual framework combining two behavioral dimensions, acceptance (from high use to non-use) and resistance (from enthusiastic support to aggressive resistance). Using qualitative case data from a telecare implementation project, they found patients' ambivalent reactions toward telehomecare (e.g., supporting it but non-using it). Their findings suggest voluntariness to be a key predictor of the variation in patients' reactions towards the telehealth solution.

In the information technology (IT) field, however, several models have been proposed to test the factors 
that influence individual IT adoption or use. Examples of theories which have been tested in the broader IT context include, but are not limited to, the Theory of Reasoned Action, the Theory of Planned Behavior, the Technology Acceptance Model, the Social Cognitive Theory, and the PC Utilization Model (e.g., $[1,7,24,27,34,38])$. In an attempt to unify the extant literature in this area, Venkatesh et al. [39] developed and validated the Unified Theory of Acceptance and Use of Technology (UTAUT) that includes four constructs related to individual adoption of IT. These predictors are: 1) Performance expectancy (i.e. individual's belief of the extent to which the system helps attaining benefits in performance); 2) Effort expectancy (i.e. extent of ease of use of the system); 3) Social influence (i.e. individual's perception of whether other people, who are important to him/her, think that the system should be used); and 4) Facilitating conditions (i.e. individual's belief of whether IT infrastructures exist to support system use).

To our knowledge, only one study has used elements of UTAUT to gain insight into the intention of older adults to use e-health solutions [37]. Analysis of surveys of 1014 respondents (57-77 years) showed that expected performance and effort were highly related to intention to use e-health. Importantly, selfefficacy was related to intention to use while social influence was not. It must be noted though that this study did not focus on a particular IT-based solution, but referred to e-health solutions as a broad concept, which may mean different things to different people.

\section{Methodology}

\subsection{Study Design}

A longitudinal evaluative study was conducted to examine the impacts of TM on patient empowerment and self-care, and explore the adoption factors among elderly patients with chronic HF. It involved a triangulation of data sources, including three rounds of surveys, and vital signs transmission from patients' residence to a central TM station at a local hospital. Outcomes data related to health services utilization were also collected at the central TM station.

TM has been conventionally investigated in the context of patients living within their own homes. This study is the first to include, in addition to patients living in their homes, patients residing in retirement homes (RHs). RHs represent flexible residence alternatives for independent seniors who desire to live in an environment where they can interact with others of their age. They simulate a home environment, where each individual usually has his/her own privacy and live in a separate suite [26]. But they also include services to make residents' stay more comfortable than if they were in their own homes (e.g., housekeeping, special meals, transportation to medical appointments).

The TM system that was used in this study consisted of a user-friendly monitor connected to a telephone line. It allowed daily data transmission about the patients (e.g., vital signs, weight - fluctuation being indicators of deterioration), and was programmed to ask the patients pertinent Yes/No questions (e.g., medication intake, complaints). The transmitted data were received by a central TM station hosted at the Heart Institute (HI) in Ottawa, and reviewed by a nurse expert who intervened as required (e.g., medications titration to optimal doses, self-care education).

Each patient living at home was given a monitor that was used for the daily transmission of his/her vital signs data and body weight. For patients residing in RHs, a central station was installed in the common area of the respective retirement home, and each patient was provided a unique swipe card that he/she can use to transmit the data to the central station at the HI. A demonstration of how the system works (connecting peripherals, using the switch for verbal prompts) was performed at the beginning of the project to ensure that patients are capable and informed on using the system.

\subsection{Survey Instrument and Data Sources}

In order to capture and understand the behavioral changes among elderly patients, which may account for the differential effectiveness and success of TM, we assessed patient empowerment and self-care, at three points in time, using existing measures in the literature. The Self-Care of Heart Failure Index [32] was used to measure self-care (11 items), while the Patient Empowerment Scale was adapted to measure patient empowerment in managing $\mathrm{HF}$ (8 items) [5]. In addition, we explored the factors related to the adoption of TM by senior patients with chronic HF. For this purpose, we used existing validated scales [39] that were adapted to fit the context of this research: performance expectancy (3 items), effort expectancy (3 items), social influence (3 items), facilitating conditions (4 items), and behavioral intention to use the system ( 3 items). The context of this research being patient-focused in non-business environment precluded the inclusion of certain items in the original scales. Two items were also added under the facilitating conditions to capture the convenience of the locations of the TM unit and the human resources (nontechnical) available to patients. Health consciousness was measured at baseline using a scale (4 items) adapted from Jayanti \& Burns [16], and the 12-item instrument developed by Ware, Kosinski \& Keller [40] 
was used to assess the participants' Quality of Life. A copy of the instruments may be obtained upon request. Last, data on services utilization (e.g., frequency of changes in medications, emergency visits, calls made to physicians) were captured at the central TM unit.

\subsection{Sampling and Data Collection}

A sample of 23 patients were recruited in this study. Given the challenges associated with studying technology use among elderly patients, careful attention was made to identify eligible candidates with chronic HF condition, who demonstrate physical and mental capability to participate in the study. Special considerations in the recruitment took into account dexterity, fall risk, mental health, etc. Given the limited research on TM use in the context of retirement homes, we also included patients from RHs. Ethics approval was obtained from two institutional review boards: the Ottawa Heart Institute Research and the University of Ottawa Research Ethics Board. All participants gave informed consent to participate in this study.

Table 1: Survey constructs and data collection rounds.

\begin{tabular}{|c|c|c|c|}
\hline Constructs and Variables* & $\mathbf{T}_{0}$ & $\mathbf{T}_{3}$ & $\mathrm{~T}_{6}$ \\
\hline Demographic Variables & $\mathrm{X}$ & & \\
\hline Performance Expectancy & $\mathrm{X}$ & & \\
\hline Effort Expectancy; & $\mathrm{X}$ & & \\
\hline Social Influence & $\mathrm{X}$ & & \\
\hline Facilitating Conditions & & $\mathrm{X}$ & \\
\hline Behavioral Intention to Use the System & $\mathrm{X}$ & & \\
\hline Health Consciousness & $\mathrm{X}$ & & \\
\hline Quality of Life & $\mathrm{X}$ & & \\
\hline Self-Care & $\mathrm{X}$ & $\mathrm{X}$ & $\mathrm{X}$ \\
\hline Patient Empowerment & $\mathrm{X}$ & $\mathrm{X}$ & $\mathrm{X}$ \\
\hline \multicolumn{4}{|c|}{$\begin{array}{l}* \text { Outcomes variables were captured at the HI telemonitoring unit } \\
\mathrm{T}_{0}=\text { After the } 1^{\text {st }} \text { week of system use; } \mathrm{T}_{3}=\text { After three months of } \\
\text { system use; } \mathrm{T}_{6}=\text { Three months following the last day of system } \\
\text { use }\end{array}$} \\
\hline
\end{tabular}

For the purpose of this study, a triangulation of data sources was used to assess the impacts of TM on patient empowerment and self-care, and explore the adoption factors among elderly suffering from $\mathrm{HF}$. Three survey instruments that captured the constructs presented above (Table 1) were administered at: $\mathrm{T}_{0}$ (after the $1^{\text {st }}$ week of system use), $\mathrm{T}_{3}$ (after three months of system use), and $\mathrm{T}_{6}$ (three months following the last day of system use). Data assessing the factors related to the adoption of TM were collected at the beginning of the study and three months following TM. Patient empowerment and patient self-care were assessed at $\mathrm{T}_{0}, \mathrm{~T}_{3}$, and $\mathrm{T}_{6}$. Out of the 23 patients, 17 (74\%) and 11 patients $(48 \%)$ completed both $\mathrm{T}_{0}$ and
$\mathrm{T}_{3}$, and $\mathrm{T}_{3}$ and $\mathrm{T}_{6}$, respectively. Outcomes data related to $\mathrm{TM}$ were collected at the TM central station.

\subsection{Data Analysis}

Descriptive data analysis was performed to present an overview of the patients' characteristics and the main behavioral and contextual factors that influence TM adoption by elderly patients. Descriptive analysis was also conducted to explore the level of patients' empowerment and self-care in the sample, and the general information on patients' outcomes and utilization of services during the study. The nonparametric Wilcoxon Signed Rank test was used to assess the significant changes in patient empowerment and self-care across the three stages of data collection; at the beginning of the study, three months following TM, and six months after the start of the study.

\section{Results}

This section presents the preliminary findings of a longitudinal study assessing the impacts TM on patient empowerment and self-care for elderly patients with chronic HF. It also explores factors that may influence their adoption of this technology. In the following paragraphs, we: 1) provide an overview of the sample and the outcomes associated with TM use; 2) present an exploratory assessment of the adoption factors related to TM; and 3) report evidence on the changes in patient empowerment and self-care among senior patients with chronic HF condition over three periods of time.

\begin{tabular}{|c|c|c|c|}
\hline \multicolumn{2}{|l|}{ Patients' Profile } & \multirow{2}{*}{$\begin{array}{c}N \\
16 \\
7\end{array}$} & \multirow{2}{*}{$\begin{array}{c}\% \\
69.6 \% \\
30.4 \%\end{array}$} \\
\hline Gender & $\begin{array}{l}\text { Male } \\
\text { Female }\end{array}$ & & \\
\hline Marital status * & $\begin{array}{l}\text { Married } \\
\text { Widowed } \\
\text { Divorced }\end{array}$ & $\begin{array}{l}15 \\
3 \\
1\end{array}$ & $\begin{array}{c}78.9 \% \\
15.8 \% \\
5.3 \%\end{array}$ \\
\hline $\begin{array}{l}\text { Highest degree of } \\
\text { education* }\end{array}$ & $\begin{array}{l}\text { High school/College } \\
\text { Undergraduate (Bachelors) } \\
\text { Master Level } \\
\text { Doctoral Level } \\
\text { Other }\end{array}$ & $\begin{array}{c}12 \\
2 \\
1 \\
1 \\
3\end{array}$ & $\begin{array}{c}63.2 \% \\
10.5 \% \\
5.3 \% \\
5.3 \% \\
15.8 \%\end{array}$ \\
\hline Primary Diagnosis & $\begin{array}{l}\text { CHF } \\
\text { Post-OP/ACS/Valve } \\
\text { ACS }\end{array}$ & $\begin{array}{c}21 \\
1 \\
1\end{array}$ & $\begin{array}{l}91.4 \% \\
4.3 \% \\
4.3 \%\end{array}$ \\
\hline $\begin{array}{l}\text { Comorbidities in addition } \\
\text { to Heart Failure?* }\end{array}$ & $\begin{array}{l}\text { Yes } \\
\text { No }\end{array}$ & $\begin{array}{c}14 \\
5\end{array}$ & $\begin{array}{l}73.7 \% \\
26.3 \%\end{array}$ \\
\hline $\begin{array}{l}\text { Types of frequent } \\
\text { comorbidities*** }\end{array}$ & $\begin{array}{l}\text { Diabetes } \\
\text { Arthritis } \\
\text { Cancer } \\
\text { Other CV } \\
\text { Other non-CV }\end{array}$ & $\begin{array}{l}5 \\
3 \\
2 \\
3 \\
6\end{array}$ & $\begin{array}{l}26.3 \% \\
15.8 \% \\
10.5 \% \\
15.8 \% \\
31.6 \%\end{array}$ \\
\hline Age (years) & $\begin{array}{l}\text { Mean } \\
{[\text { Min-Max] }}\end{array}$ & \multicolumn{2}{|c|}{$\begin{array}{c}75.2 \\
{[60-94]}\end{array}$} \\
\hline
\end{tabular}




\section{Proceedings of the 50 $0^{\text {th }}$ Hawaii International Conference on System Sciences - 2017}

\subsection{Sample characteristics and TM outcomes}

The sample consisted of five patients living in RHs and 18 patients in their own homes. As indicated in Table 2, the majority of the patients were married men, with a mean age of 75.2 years. The highest degree of education was high school/college; three patients had completed Grade 4 and 5. The majority had chronic HF identified as a primary diagnosis, and reported multiple comorbidities including diabetes and other noncardiovascular diseases (e.g., fractures, bleeding).

\begin{tabular}{|c|c|c|c|}
\hline Outcomes & $\begin{array}{l}\text { RH Patients } \\
\text { Mean } \\
\text { [Min-Max] } \\
(\mathbf{n}=\mathbf{5})\end{array}$ & $\begin{array}{c}\text { Home Patients } \\
\text { Mean } \\
\text { [Min-Max] } \\
(\mathrm{n}=\mathbf{1 8})\end{array}$ & $\begin{array}{c}\text { Total } \\
\text { Mean } \\
{\left[\begin{array}{c}\text { Min-Max] } \\
(\mathrm{n}=\mathbf{2 3})\end{array}\right.}\end{array}$ \\
\hline \# of adjustment of diuretics & $\begin{array}{c}3.4 \\
{[0-9]}\end{array}$ & $\begin{array}{c}3.1 \\
{[0-9]}\end{array}$ & $\begin{array}{c}3.1 \\
{[0-9]}\end{array}$ \\
\hline $\begin{array}{l}\text { \# adjustment of CHF best } \\
\text { practice Medications }\end{array}$ & $\begin{array}{c}1.2 \\
{[0-4]}\end{array}$ & $\begin{array}{c}1.4 \\
{[0-6]}\end{array}$ & $\begin{array}{c}1.4 \\
{[0-6]}\end{array}$ \\
\hline \# patient calls by $\mathrm{RN}$ & $\begin{array}{c}9.2 \\
{[0-18]}\end{array}$ & $\begin{array}{c}11.2 \\
{[3-23]}\end{array}$ & $\begin{array}{c}10.8 \\
{[0-23]}\end{array}$ \\
\hline \# Physician calls & $\begin{array}{c}0.80 \\
{[0-3]}\end{array}$ & $\begin{array}{c}0.6 \\
{[0-3]}\end{array}$ & $\begin{array}{c}0.7 \\
{[0-3]}\end{array}$ \\
\hline \# Emergency Room visits & - & $\begin{array}{c}0.3 \\
{[0-2]}\end{array}$ & $\begin{array}{c}0.3 \\
{[0-2]}\end{array}$ \\
\hline Hospital admissions & $\begin{array}{c}0.2 \\
{[0-1]}\end{array}$ & $\begin{array}{c}0.4 \\
{[0-3]}\end{array}$ & $\begin{array}{c}0.4 \\
{[0-3]}\end{array}$ \\
\hline
\end{tabular}

We assessed the major outcomes associated with TM among patients over the period of the study. Overall, the number of physician calls (mean=0.7), emergency room visits (mean $=0.3$ ), and hospital admissions (mean $=0.7$ ) was relatively small and comparable between the patients living at home and in RHs (Table 3). The number of adjustments for congestive HF medications based on best practices (e.g., Beta Blockers, Ace Inhibitors), as well diuretics adjustments made due to change in patients' weight or symptoms, were also comparable between the two groups (mean=1.4 and 3.1, respectively).

\subsection{Adoption / contextual factors}

In order to explore the adoption/contextual factors related to TM use by elderly HF patients, we conducted a survey at baseline $\left(\mathrm{T}_{0}\right)$ that measured the performance expectancy of this technology, the extent of effort they perceive that they need to put in order to use TM, the social influence around them in relation to technology adoption, as well as their overall intention to use TM in the future (Table 4). On a 7-point scale, the 19 patients who completed the survey perceived that the system would relatively help them in the management (mean=5.95), monitoring (mean=5.84), and stabilization (mean=5.21) of their medical condition. With respect to effort expectancy, they considered that learning and using the system was easy (mean $>6$ for all three questions). They indicated that the social influence of people around them (e.g., people important to them, nurses/physicians) was supportive of this technology. Their intention to use TM over the three months period of the study was very high.

\begin{tabular}{|c|c|c|}
\hline \multicolumn{2}{|l|}{ Constructs and Measures } & \multirow{2}{*}{$\begin{array}{c}\text { T0 }(N=19) \\
\text { Mean } \\
\text { [Min-Max] } \\
5.95 \\
{[4-7]}\end{array}$} \\
\hline $\begin{array}{l}\text { Performance } \\
\text { Expectancy (1-7 scale) }\end{array}$ & $\begin{array}{l}\text { I anticipate the system will be useful in the } \\
\text { management of my illness }\end{array}$ & \\
\hline & $\begin{array}{l}\text { Using the System will enable me to track and monitor } \\
\text { my medical condition more quickly }\end{array}$ & $\begin{array}{l}5.84 \\
{[3-7]}\end{array}$ \\
\hline & $\begin{array}{l}\text { I believe that the system will help in stabilizing my } \\
\text { medical condition }\end{array}$ & $\begin{array}{l}5.21 \\
{[2-7]}\end{array}$ \\
\hline \multirow[t]{3}{*}{$\begin{array}{l}\text { Effort Expectancy } \\
\text { (1-7 scale) }\end{array}$} & $\begin{array}{l}\text { The instructions when interacting with the system are } \\
\text { clear and simple }\end{array}$ & 6.68 \\
\hline & I find the system easy to use & 6.58 \\
\hline & Learning to use the system adequately is easy for me & $\begin{array}{l}6.47 \\
{[5-7]}\end{array}$ \\
\hline \multirow[t]{3}{*}{$\begin{array}{l}\text { Social Influence } \\
\text { (1-7 scale) }\end{array}$} & $\begin{array}{l}\text { People who influence my health behavior think that I } \\
\text { should use the system }\end{array}$ & 6.17 \\
\hline & $\begin{array}{l}\text { People who are important to me think that I should use } \\
\text { the system }\end{array}$ & $\begin{array}{l}6.47 \\
{[4-7]}\end{array}$ \\
\hline & $\begin{array}{l}\text { Physicians/nurses who follow my condition think that I } \\
\text { should use the system on a regular basis }\end{array}$ & $\begin{array}{l}6.24 \\
{[4-7]}\end{array}$ \\
\hline \multirow{3}{*}{$\begin{array}{l}\text { Behavioral Intention } \\
\text { to use the System } \\
\text { (1-7 scale) }\end{array}$} & $\begin{array}{l}\text { I intend to use the system on a regular basis in the next } \\
\text { three months }\end{array}$ & $\begin{array}{l}6.63 \\
{[4-7]}\end{array}$ \\
\hline & $\begin{array}{l}\text { I predict I will use the system daily in the next three } \\
\text { months }\end{array}$ & $\begin{array}{l}6.68 \\
{[6-7]}\end{array}$ \\
\hline & $\begin{array}{l}\text { I plan to use the system as recommended in the next } \\
\text { three months }\end{array}$ & $\begin{array}{l}6.79 \\
{[6-7]}\end{array}$ \\
\hline \multirow[t]{5}{*}{$\begin{array}{l}\text { Health Consciousness } \\
\text { (1-5 scale) }\end{array}$} & $\begin{array}{l}\text { I read more health-related articles now than I did in the } \\
\text { past. }\end{array}$ & $\begin{array}{l}3.63 \\
{[1-5]}\end{array}$ \\
\hline & I am interested in information about my health & $\begin{array}{l}4.37 \\
{[2-5]}\end{array}$ \\
\hline & I am concerned about my health all the time & $\begin{array}{l}4.00 \\
{[2-5]}\end{array}$ \\
\hline & $\begin{array}{l}\text { I am interested in information about the prevention and } \\
\text { management of heart failure }\end{array}$ & $\begin{array}{l}4.53 \\
{[2-5]}\end{array}$ \\
\hline & Constructs and Measures & $\begin{array}{c}T 3(\mathrm{~N}=20) \\
\text { Mean } \\
\text { [Min-Max] }\end{array}$ \\
\hline \multirow{4}{*}{$\begin{array}{l}\text { Facilitating } \\
\text { Conditions } \\
\text { (1-7 scale) }\end{array}$} & I had sufficient training on how to use the system & $\begin{array}{l}6.45 \\
{[5-7]}\end{array}$ \\
\hline & $\begin{array}{l}\text { People around me (e.g., peers, friends, nurses) assist } \\
\text { me in using the system appropriately }\end{array}$ & $\begin{array}{l}5.50 \\
{[1-7]}\end{array}$ \\
\hline & $\begin{array}{l}\text { The location of the telemonitoring unit in my } \\
\text { home/retirement home is convenient to me }\end{array}$ & $\begin{array}{l}6.55 \\
{[1-7]}\end{array}$ \\
\hline & $\begin{array}{l}\text { Technical support was available to assist me with } \\
\text { technical problems related to the system }\end{array}$ & $\begin{array}{l}5.78 \\
{[1-7]}\end{array}$ \\
\hline
\end{tabular}

Assessment of health consciousness revealed that patients indicated concern about their health condition and high interest in getting information about their health and the management of HF (mean=4.37 and 4.53 , respectively). Analysis of their quality of life also showed that the majority suffered problems (e.g., restricted activity, limited energy), which affected their overall well-being (measures available upon request).

Assessment of the facilitating conditions was done at the end of the TM period; 20 patients completed the survey at $\mathrm{T}_{3}$ (Table 4). They indicated that training was sufficient and the technology set-up in their residence was convenient. The means for the measures of availability of people around them to assist with using the technology, and of technical support, were slightly lower than other adoption factors, but still relatively high (mean=5.50 and 5.78, respectively). 


\section{Proceedings of the 50 $0^{\text {th }}$ Hawaii International Conference on System Sciences - 2017}

\subsection{Patient empowerment and self-care}

A main objective of this study was to examine the impacts of TM on patient empowerment and self-care, and assess whether these effects are sustained over time. For this purpose, we used a longitudinal study design that involved three rounds of data collection.

\begin{tabular}{|c|c|c|c|}
\hline Constructs and Measures & $\begin{array}{c}T 0(N=19) \\
\text { Mean } \\
\text { [Min-Max] }\end{array}$ & $\begin{array}{c}T 3(N=20) \\
\text { Mean } \\
{[\text { Min-Max] }}\end{array}$ & $\begin{array}{c}\text { T6 }(\mathrm{N}=15) \\
\text { Mean } \\
\text { [Min-Max] }\end{array}$ \\
\hline \multicolumn{4}{|l|}{ Patient Empowerment (1-7 scale) } \\
\hline $\begin{array}{l}\text { I have enough clinical information to manage my } \\
\text { heart failure condition. }\end{array}$ & $\begin{array}{l}5.12 \\
{[1-7]}\end{array}$ & $\begin{array}{l}5.75 \\
{[4-7]}\end{array}$ & $\begin{array}{c}5.5 \\
{[4-6]}\end{array}$ \\
\hline $\begin{array}{l}\text { I am capable of making decisions related to my heart } \\
\text { failure condition. }\end{array}$ & $\begin{array}{l}5.50 \\
{[1-7]}\end{array}$ & $\begin{array}{l}5.90 \\
{[3-7]}\end{array}$ & $\begin{array}{c}5.5 \\
{[4-7]}\end{array}$ \\
\hline $\begin{array}{l}\text { I feel that I am involved in the decision making } \\
\text { process related to my heart failure condition. }\end{array}$ & $\begin{array}{l}5.61 \\
{[2-7]}\end{array}$ & $\begin{array}{l}5.65 \\
{[1-7]}\end{array}$ & $\begin{array}{l}5.58 \\
{[3-7]}\end{array}$ \\
\hline $\begin{array}{l}\text { I am capable of being involved in the decision } \\
\text { making process related to my heart failure condition. }\end{array}$ & $\begin{array}{l}6.47 \\
{[4-7]}\end{array}$ & $\begin{array}{l}6.20 \\
{[3-7]}\end{array}$ & $\begin{array}{l}6.42 \\
{[4-7]}\end{array}$ \\
\hline $\begin{array}{l}\text { I need the support of family and friends to manage } \\
\text { my heart failure condition. }\end{array}$ & $\begin{array}{l}4.44 \\
{[1-7]}\end{array}$ & $\begin{array}{l}4.40 \\
{[1-7]}\end{array}$ & $\begin{array}{l}3.73 \\
{[1-7]}\end{array}$ \\
\hline $\begin{array}{l}\text { I am capable of finding relevant answers to questions } \\
\text { that I have related to my heart condition. }\end{array}$ & $\begin{array}{l}5.67 \\
{[1-7]}\end{array}$ & $\begin{array}{l}5.85 \\
{[3-7]}\end{array}$ & $\begin{array}{l}6.00 \\
{[4-7]}\end{array}$ \\
\hline I am familiar with the symptoms of heart failure. & $\begin{array}{l}5.83 \\
{[3-7]}\end{array}$ & $\begin{array}{l}6.05 \\
{[5-7]}\end{array}$ & $\begin{array}{l}5.75 \\
{[2-7]}\end{array}$ \\
\hline $\begin{array}{l}\text { I am familiar with the preventive measures that } \\
\text { reduce deterioration in heart failure. }\end{array}$ & $\begin{array}{l}5.47 \\
{[2-7]}\end{array}$ & $\begin{array}{l}6.00 \\
{[5-7]}\end{array}$ & $\begin{array}{l}5.83 \\
{[4-7]}\end{array}$ \\
\hline
\end{tabular}

Overall, patient empowerment was moderate-high at all three points in time (Table 5). A general trend of higher scores on patient empowerment measures were observed at $\mathrm{T}_{3}$ as compared to $\mathrm{T}_{0}$ and $\mathrm{T}_{6}$. Only two questions did not follow this trend. The capability to be involved in the decision making process decreased at $\mathrm{T}_{3}$. And the capability to find relevant answers to one's condition, had increasingly higher scores at $\mathrm{T}_{3}$ and $\mathrm{T}_{6}$. The need of family and friends' support in the management of HF condition was also lower over time.

Two dimensions of self-care, self-care maintenance and self-care management, were examined in this study. Generally, patients reported relatively high level of self-care maintenance at $\mathrm{T}_{0}, \mathrm{~T}_{3}$, and $\mathrm{T}_{6}$, despite a decreasing trend over time for three measures (Table 6). Yet, taking part in regular physical activity improved at $\mathrm{T}_{3}$, but was not sustained at $\mathrm{T}_{6}$. And eating low salt diet improved at $T_{3}$ and $T_{6}$, respectively.

For self-care management, patients reported an overall high score on all measures with the exception of three questions: 1) recognizing trouble breathing and ankle swelling as symptoms of HF; 2) taking an extra water pill when these symptoms arise; and 3) confidence that a used remedy helped or not (Table 6). As with patient empowerment measures, the same trend of higher scores on self-management indicators were observed at $T_{3}$ as compared to $T_{0}$ and $T_{6}$. The measures that did not show this trend, but rather a consistent increase in the level of self-care over time included: reducing fluid intake when having trouble breathing or ankle swelling; and confidence in the ability to evaluate the importance of one's symptoms. The frequency of trouble breathing and ankle swelling was also lower at $T_{3}$ and $T_{6}$.

\begin{tabular}{|c|c|c|c|}
\hline Self-Care Maintenance (1-4 scale) & $\begin{array}{c}T 0(N=19) \\
\text { Mean } \\
{[\text { Min-Max] }}\end{array}$ & $\begin{array}{c}T 3(N=20) \\
\text { Mean } \\
{[\text { Min-Max] }}\end{array}$ & $\begin{array}{l}\text { T6 }(N=15) \\
\text { Mean } \\
{[\text { Min-Max] }}\end{array}$ \\
\hline Weigh yourself daily & $\begin{array}{c}3.74 \\
{[1-4]}\end{array}$ & $\begin{array}{l}3.50 \\
{[2-4]}\end{array}$ & $\begin{array}{l}3.00 \\
{[1-4]}\end{array}$ \\
\hline Eat a low salt diet & $\begin{array}{l}3.53 \\
{[2-4]}\end{array}$ & $\begin{array}{l}3.74 \\
{[3-4]}\end{array}$ & $\begin{array}{l}3.83 \\
{[3-4]}\end{array}$ \\
\hline Take part in regular physical activity & $\begin{array}{l}2.68 \\
{[1-4]}\end{array}$ & $\begin{array}{l}3.05 \\
{[1-4]}\end{array}$ & $\begin{array}{l}2.58 \\
{[1-3]}\end{array}$ \\
\hline Keep your weight down & $\begin{array}{l}3.26 \\
{[1-4]}\end{array}$ & $\begin{array}{l}3.25 \\
{[2-4]}\end{array}$ & $\begin{array}{l}2.92 \\
{[1-4]}\end{array}$ \\
\hline Get a flu shot every year & $\begin{array}{l}3.84 \\
{[1-4]}\end{array}$ & $\begin{array}{l}3.55 \\
{[1-4]}\end{array}$ & $\begin{array}{c}3.42 \\
{[1-4]}\end{array}$ \\
\hline Self-Care Management (1-4 scale) & $\begin{array}{c}T 0(N=19) \\
\text { Mean } \\
\text { [Min-Max] }\end{array}$ & $\begin{array}{l}T 3(N=20) \\
\text { Mean } \\
\text { [Min-Max] }\end{array}$ & $\begin{array}{l}\text { T6 }(\text { N }=15) \\
\text { Mean } \\
{[\text { Min-Max }]}\end{array}$ \\
\hline $\begin{array}{l}\text { Many patients have symptoms due to their heart failure. } \\
\text { Trouble breathing and ankle swelling are common symptoms. } \\
\text { In the past three months, have you had trouble breathing or } \\
\text { ankle swelling? (yes) }\end{array}$ & $18(94.7 \%)$ & $12(63.2 \%)$ & $8(66.7 \%)$ \\
\hline $\begin{array}{l}\text { The last time you had trouble breathing or ankle swelling, } \\
\text { How quickly did you recognize it as a symptom of HF?* }\end{array}$ & $\begin{array}{l}2.68 \\
{[0-4]}\end{array}$ & $\begin{array}{l}2.70 \\
{[0-4]}\end{array}$ & $\begin{array}{l}2.42 \\
{[0-4]}\end{array}$ \\
\hline $\begin{array}{l}\text { Listed below are remedies that people with heart failure use. } \\
\text { When you have trouble breathing or ankle swelling, how likely } \\
\text { are you to try one of these remedies? } \\
\text { Reduce the salt in your diet }\end{array}$ & $\begin{array}{l}3.56 \\
{[2-4]}\end{array}$ & $\begin{array}{l}3.70 \\
{[2-4]}\end{array}$ & $\begin{array}{c}3.42 \\
{[1-4]}\end{array}$ \\
\hline Reduce your fluid intake & $\begin{array}{l}3.37 \\
{[1-4]}\end{array}$ & $\begin{array}{l}3.60 \\
{[1-4]}\end{array}$ & $\begin{array}{l}2.67 \\
{[1-4]}\end{array}$ \\
\hline Take an extra water pill & $\begin{array}{l}2.74 \\
{[1-4]}\end{array}$ & $\begin{array}{l}3.11 \\
{[1-4]}\end{array}$ & $\begin{array}{l}2.92 \\
{[1-4]}\end{array}$ \\
\hline Call your doctor or nurse for guidance & $\begin{array}{l}3.06 \\
{[1-4]}\end{array}$ & $\begin{array}{l}3.10 \\
{[1-4]}\end{array}$ & $\begin{array}{l}2.75 \\
{[2-4]}\end{array}$ \\
\hline Get a flu shot every year & $\begin{array}{l}3.84 \\
{[1-4]}\end{array}$ & $\begin{array}{l}3.40 \\
{[1-4]}\end{array}$ & $\begin{array}{l}3.33 \\
{[1-4]}\end{array}$ \\
\hline $\begin{array}{l}\text { If you tried any of these remedies the last time you had trouble } \\
\text { breathing or ankle swelling, ... } \\
\text { How sure were you that the remedy helped or not?* }\end{array}$ & $\begin{array}{l}2.16 \\
{[0-4]}\end{array}$ & $\begin{array}{l}2.84 \\
{[0-4]}\end{array}$ & $\begin{array}{l}2.27 \\
{[0-4]}\end{array}$ \\
\hline $\begin{array}{l}\text { How confident are you that you can evaluate the importance of } \\
\text { your symptoms? }\end{array}$ & $\begin{array}{l}3.11 \\
{[1-4]}\end{array}$ & $\begin{array}{l}3.40 \\
{[2-4]}\end{array}$ & $\begin{array}{l}3.42 \\
{[2-4]}\end{array}$ \\
\hline $\begin{array}{l}\text { Generally, how confident are you that you can recognize } \\
\text { changes in your health if they occur? }\end{array}$ & $\begin{array}{l}3.21 \\
{[2-4]}\end{array}$ & $\begin{array}{l}3.47 \\
{[2-4]}\end{array}$ & $\begin{array}{l}3.42 \\
{[2-4]}\end{array}$ \\
\hline $\begin{array}{l}\text { Generally, how confident are you that you can do something } \\
\text { that will relieve your symptoms? }\end{array}$ & $\begin{array}{l}2.79 \\
{[1-4]}\end{array}$ & $\begin{array}{l}3.25 \\
{[1-4]}\end{array}$ & $\begin{array}{l}3.17 \\
{[2-4]}\end{array}$ \\
\hline $\begin{array}{l}\text { How confident are you that you can evaluate the effectiveness } \\
\text { of whatever you do to relieve your symptoms? }\end{array}$ & $\begin{array}{l}2.79 \\
{[1-4]}\end{array}$ & $\begin{array}{l}3.25 \\
{[1-4]}\end{array}$ & $\begin{array}{l}3.08 \\
{[2-4]}\end{array}$ \\
\hline
\end{tabular}

The paired analysis of significant difference on the measures of patient empowerment only showed one statistically significant change (Table 7). Surprisingly, it was associated with a decrease in the capability of patients to be involved in the decision making process related to their HF condition, which was observed three months after the beginning of the study but remained relatively high $($ mean $=6.20)$. 


\section{Proceedings of the $50^{\text {th }}$ Hawaii International Conference on System Sciences - 2017}

Table 7: Wilcoxon sign-rank test for significant differences in patient empowerment at $T_{0}, T_{3}$, and $T_{6}$.

\begin{tabular}{|c|c|c|}
\hline Patient Empowerment Measures & $\begin{array}{l}\text { Z-Test } \\
\text { [T0-T3] }\end{array}$ & $\begin{array}{l}\text { Z Test } \\
{[\text { T3-T6] }}\end{array}$ \\
\hline $\begin{array}{l}\text { I have enough clinical information to manage my heart failure } \\
\text { condition. }\end{array}$ & -1.552 & 0.000 \\
\hline $\begin{array}{l}\text { I am capable of making decisions related to my heart failure } \\
\text { condition. }\end{array}$ & -0.863 & -0.302 \\
\hline $\begin{array}{l}\text { I feel that I am involved in the decision making process related } \\
\text { to my heart failure condition. }\end{array}$ & -0.587 & -0.632 \\
\hline $\begin{array}{l}\text { I am capable of being involved in the decision making process } \\
\text { related to my heart failure condition. }\end{array}$ & $-2.111^{* *}$ & -1.633 \\
\hline $\begin{array}{l}\text { I need the support of family and friends to manage my heart } \\
\text { failure condition. }\end{array}$ & -1.095 & -0.570 \\
\hline $\begin{array}{l}\text { I am capable of finding relevant answers to questions that I have } \\
\text { related to my heart condition. }\end{array}$ & -0.159 & -0.647 \\
\hline I am familiar with the symptoms of heart failure. & -0.866 & -0.302 \\
\hline $\begin{array}{l}\text { I am familiar with the preventive measures that reduce } \\
\text { deterioration in heart failure. }\end{array}$ & -0.811 & -0.265 \\
\hline $\begin{array}{l}* \text { Significant at } 0.1 \\
* * \text { Significant at } 0.05 \\
* * * \text { Significant at } 0.01\end{array}$ & & \\
\hline
\end{tabular}

The paired analysis of self-care measures revealed statistically significant changes on six indicators (Table 8). First, a statistically significant decrease in the variable assessing the frequency of weighing oneself was observed over time, and sustained at $\mathrm{T}_{6}$. Second, a statistically significant decline in the likelihood of reducing fluid intake as a remedy for trouble breathing and ankle swelling' was observed at $\mathrm{T}_{6}$ indicating sustaining of this behavior over time. Third, the likelihood of taking an extra pill as a remedy for breathing and ankle swelling symptoms statistically increased three months after TM was introduced. Most importantly, a statistically significant increase in patients' confidence in their ability to evaluate the importance of their symptoms, take measures to relieve these symptoms, and evaluate the effectiveness of such measures, was observed from $T_{0}$ (baseline) to $T_{3}$.

\section{Discussion}

HF patients often witness fast deterioration in their condition accompanied by an increase in their weight and other symptoms that last days and weeks before they actually seek care [8]. They often end up readmitted to a hospital within three to six months after their discharge due to poor self-care and their inability to detect early signs of deterioration [22]. In an integrative review, Zavertnik [43] reported that senior patients with HF usually encounter challenges in engaging in self-care practices given their special needs as a patient group. The author stressed the limited studies on self-care in older HF patients, and recommended that these patients be studied as a separate cohort to identify best approaches for promoting effective self-care [43]. In parallel, in a literature review on the impacts of telehealth for HF patient, Radhakrishnan and Jacelon [31] recommended that future studies explore the effect of telehealth on self-care outcomes using strong study designs and rigorous data collection procedures. Yet, a scan of the IT literature reveals limited research on the facilitators/barriers for the adoption of telehealth by older patients [11]. This research addresses these areas, and presents preliminary evidence on the adoption factors and impacts of TM on patient empowerment and self-care for senior with chronic HF.

\begin{tabular}{|c|c|c|}
\hline Self-Care Measures & $\begin{array}{l}\text { Z-Test } \\
\text { [T0-T3] }\end{array}$ & $\begin{array}{l}\text { Z Test } \\
\text { [T3-T6] }\end{array}$ \\
\hline \multicolumn{3}{|l|}{ Self-Care Maintenance } \\
\hline Weigh yourself daily & $-1.667^{*}$ & $-2.060 * *$ \\
\hline Eat a low salt diet & -0.577 & -1.414 \\
\hline Take part in regular physical activity & -0.577 & -0.816 \\
\hline Keep your weight down & -0.775 & -0.816 \\
\hline Get a flu shot every year & 0.000 & -1.000 \\
\hline \multicolumn{3}{|l|}{ Self-Care Management } \\
\hline $\begin{array}{l}\text { Many patients have symptoms due to their heart failure. Trouble breathing and } \\
\text { ankle swelling are common symptoms. } \\
\text { In the past three months, have you had trouble breathing or ankle swelling? }\end{array}$ & NS $¥$ & NS $¥$ \\
\hline $\begin{array}{l}\text { The last time you had trouble breathing or ankle swelling, } \\
\text { How quickly did you recognize it as a symptom of heart failure? }\end{array}$ & -0.604 & -1.633 \\
\hline $\begin{array}{l}\text { Listed below are remedies that people with heart failure use. When you have } \\
\text { trouble breathing or ankle swelling, how likely are you to try one of these } \\
\text { remedies? } \\
\text { Reduce the salt in your diet }\end{array}$ & -0.447 & -1.000 \\
\hline Reduce your fluid intake & -1.000 & $-1.730^{*}$ \\
\hline Take an extra water pill & $-1.725^{*}$ & -0.425 \\
\hline Call your doctor or nurse for guidance & 0.000 & 0.000 \\
\hline Get a flu shot every year & -1.342 & -1.000 \\
\hline $\begin{array}{l}\text { If you tried any of these remedies the last time you had trouble breathing or ankle } \\
\text { swelling, ... } \\
\text { How sure were you that the remedy helped or not? }\end{array}$ & -1.565 & -0.212 \\
\hline How confident are you that you can evaluate the importance of your symptoms? & $-1.667^{*}$ & -0.577 \\
\hline $\begin{array}{l}\text { Generally, how confident are you that you can recognize changes in your health if } \\
\text { they occur? }\end{array}$ & -1.633 & -0.577 \\
\hline $\begin{array}{l}\text { Generally, how confident are you that you can do something that will relieve your } \\
\text { symptoms? }\end{array}$ & $-2.333^{* *}$ & -0.378 \\
\hline $\begin{array}{l}\text { How confident are you that you can evaluate the effectiveness of whatever you do } \\
\text { to relieve your symptoms? }\end{array}$ & $-2.646 * * *$ & -1.134 \\
\hline \multicolumn{3}{|c|}{$\begin{array}{l}\text { *Significant at } 0.1 \quad ¥ \text { non-significant p-value on McNemar test } \\
* \text { * Significant at } 0.05\end{array}$} \\
\hline
\end{tabular}

Overall, the patients in this study perceived value in using TM, and did not expect this technology to be difficult to use. The social influence of people close to them was positive and their intention to use the system was high, with supportive facilitating conditions. These are in line with the findings by de Veer et al [37] who assessed the determinants of intention to use e-Health by older people and found that the majority perceived e-health easy to use and learn. Interestingly, similar to their findings, the patients in this study reported lower levels of performance expectancy (i.e. usefulness) compared to effort expectancy and social influence.

Overall, the patients reported moderate-high level of patient empowerment at $T_{0}, T_{3}$, and $T_{6}$, with a trend of higher scores at $\mathrm{T}_{3}$; this indicates that the impact of TM seems to slightly decline six months after the 


\section{Proceedings of the $50^{\text {th }}$ Hawaii International Conference on System Sciences - 2017}

beginning of TM. Surprisingly, the capability to be involved in the decision making related to $\mathrm{HF}$ significantly decreased at $\mathrm{T}_{3}$. The reasons may be attributed to the structured approach of TM, which is very systematic in monitoring symptoms and addressing them based on available guidelines, leaving less room for improvisation. Nevertheless, a drop in the need of family/friends' support in the management of HF was observed, paralleled by an increase in their ability to find relevant answers to their questions about their condition over time. This may be attributed to the patients taking more control over the condition.

The findings related to patient self-care show a generally high level of self-care maintenance and management, with the exception of three measures. First, the ability to quickly recognize trouble breathing and ankle swelling as symptoms of HF was moderate, which stresses the value of TM in following-up this group of patients and timely detecting deterioration in their condition, which otherwise may be missed. Second, these elderly patients did not seem to be likely to take an extra water pill when these symptoms appear. This is further indicative of the importance of connecting them with a provider to advise them on this, as per the TM model, prior to worsening of their condition necessitating an emergency visit or a hospital admission. Third, interestingly, the surveyed patients appeared to lack confidence on whether a remedy that is used helps or not. Based on these findings, we posit that a targeted patient education model focusing on these three particular areas deserves consideration to improve senior patients' level of self-care.

A similar trend, as with patient empowerment, was observed for self-care management in terms of higher level of self-care at $\mathrm{T}_{3}$ compared to $\mathrm{T}_{0}$ and $\mathrm{T}_{6}$. This may be explained by a slight regression, six months after the beginning of the study, in the ability to selfcare once TM stops. Nevertheless, the average on these measures of self-management remained high.

Assessment of significance of TM impacts on selfcare revealed interesting results. A statistically significant decrease in patients' reporting weighing themselves daily was observed at $\mathrm{T}_{3}$ and $\mathrm{T}_{6}$. This necessitates particular attention as there seems to be a risk of patients relying on TM and acquiring a passive behavior in terms of monitoring their weight, which may stay with them after getting off the TM intervention. Thus, educational efforts should be made to remind patients of the importance of weighing themselves as a means to identify early deterioration in their condition, should fluctuations occur in their weight. In addition, although the number of patients that reported having had trouble breathing and ankle swelling was lower at $\mathrm{T}_{3}$ and $\mathrm{T}_{6}$ compared to $\mathrm{T}_{0}$, the self-care dimension related to treatment compliance reveals that patients were likely to sustain the behavior of reducing fluid intake when having these symptoms acquired during TM. Yet, although their likelihood of taking an extra water pill to address the symptoms increases at the end of the TM period $\left(\mathrm{T}_{3}\right)$, they don't seem to be able to retain this behavior at $\mathrm{T}_{6}$. This may be attributed to the fact that patients may be less comfortable taking a pill without consulting a health professional, as opposed to reducing their fluid intake.

Importantly, the impact of TM on self-management was mostly observed at the level of increase in patients' confidence in their self-care ability, which was statistically significant three months after TM. This is in line with recent studies that showed that TM has the potential to educate patients and enhance their self-care skills [3,33]. Specifically, the patients reported higher levels of confidence in evaluating their symptoms, doing something to relieve these symptoms, and evaluating the effectiveness of what they do. This is particularly important for senior patients as it presents opportunities for leveraging TM to manage them at home, while improving their self-care. This further addresses prior concerns about lack of knowledge and misconceptions among HF patients, which may lead to improper self-care skills and lack of confidence in these skills [21]. Hence, TM may be leveraged as a tool to educate elderly patients with HF and improve their self-efficacies.

This study contributes to the literature on TM by focusing on a group of potential technology users, senior patients, who have been understudied. To date, limited research have investigated the adoption factors among senior patients for specific IT solutions. Although the study by de Veer et al (2015) examined the determinants of intention to use IT, they considered e-health solutions in general and the sample of elderly surveyed was not involved in any specific intervention. This research contributes to this area by assessing the adoption factors related to a specific TM system among elderly patients with chronic HF, and present evidence on its impacts on patient self-care and empowerment. Future studies should build cumulative knowledge in this area and test the UTAUT constructs in the context of adoption of specific IT solutions, especially among elderly patients.

It is important to note that the recruitment process of elderly patients was challenging, especially that this project involved the use of technology necessitating a certain level of functional ability and mental health. Thus, we recognize the limitations of the small sample size in this research. Nevertheless, the longitudinal nature of the study, along with the detailed measures used, contributes to this research area and sets the stage for future studies examining the adoption factors and impacts with larger samples of senior patients. 


\section{Proceedings of the $50^{\text {th }}$ Hawaii International Conference on System Sciences - 2017}

With the population aging and increasing prevalence of chronic diseases, leveraging technology to support the management of elderly patients with chronic diseases presents an opportunity to prevent unnecessary emergency visits and hospitalizations. These findings may inform practitioners and policymakers by presenting preliminary evidence on the positive effect of TM on senior patients' self-care and empowerment, and highlighting the positive attitude and receptiveness of senior patients toward TM.

In addition, this study is the first to involve patients living in RHs, which is an environment that has not been considered in prior TM studies. With population aging and the decrease in potential support ratios, we expect that the number of residents in RHs will increase over time. Based on this research, we strongly recommend that future $\mathrm{TM}$ projects consider patients living in RHs, as they represent an increasing proportion of the elderly population, and merit attention when examining the facilitators/barriers and impacts of this technology.

Last, in order to get more insight about TM adoption in RHs, we conducted five post-hoc interviews with directors of $\mathrm{RH}$ and long-term care facilities in the same area where this project was conducted. Interviews revealed limited understanding of TM among administrators, and confusion in some cases, about its functionality. It was mostly perceived as a technology strictly used in the context of remote/rural areas where there is limited number of specialists. Nevertheless, when explaining to the respondents how TM works, they expressed a positive reaction to this technology, and welcomed the opportunity to leverage it to improve patient care, without impacting staff workload.

\section{Conclusion}

The use of telehealth in general, and TM in particular, among senior patients is expected to increase in light of the worldwide population aging and constraining limited resources. Hence, it is essential to understand the behavioral/contextual factors that may promote or hinder wider adoption of TM by elderly patients, as well as the impacts of this technology on patient empowerment and self-care. The findings of this study show that elderly patients are capable of using TM for the management of HF with no reported barriers. A longitudinal analysis of impacts in relation to self-care revealed significant positive effects of TM on the confidence of senior patients in their self-care ability to evaluate their symptoms, address them, evaluate the effectiveness of the measures they take, and sustain a reducing fluid intake behavior. TM may be leveraged as a tool to support senior patients' education about their condition, enhance their knowledge, and improve their self-care. Future studies involving larger samples of patients, including patients living in RHs, may further enrich the literature in this area, and contribute additional evidence of value to policy makers and health care providers alike.

\section{References}

[1] Bhattacherjee, A. and Premkumar, G. "Understanding changes in belief and attitude toward information technology usage: a theoretical model and longitudinal test." MIS quarterly, (2004), pp. 229-254.

[2] Bloom, D.E. "7 Billion and Counting." Science 333, 6042 (2011), pp. 562-569.

[3] Boyne, J.J., Vrijhoef, H.J., Spreeuwenberg, M., et al. "Effects of tailored telemonitoring on heart failure patients' knowledge, self-care, self-efficacy and adherence: A randomized controlled trial." European Journal of Cardiovascular Nursing 13, 3 (2014), pp. 243-252.

[4] Bui, A.L., Horwich, T.B., and Fonarow, G.C. "Epidemiology and risk profile of heart failure." Nature Reviews Cardiology 8, 1 (2011), pp. 30-41.

[5] Bulsara, C., Styles, I., Ward, A.M., and Bulsara, M. "The psychometrics of developing the patient empowerment scale." Journal of psychosocial oncology 24, 2 (2006), pp. 116.

[6] Bulsara, C., Ward, A., and Joske, D. "Haematological cancer patients: achieving a sense of empowerment by use of strategies to control illness." Journal of Clinical Nursing 13, 2 (2004), pp. 251-258.

[7] Chau, P.Y. and Hu, P.J.-H. "Information technology acceptance by individual professionals: A model comparison approach.” Decision sciences 32, 4 (2001), pp. 699-719.

[8] Chaudhry, S.I., Phillips, C.O., Stewart, S.S., et al. "Telemonitoring for patients with chronic heart failure: a systematic review." Journal of cardiac failure 13, 1 (2007), pp. 56-62.

[9] Coulter, A., Parsons, S., and Askham, J. "Where are the patients in decision-making about their own care." World Health Organization, (2008).

[10] Department of Health. Building Telecare in England. Department of Health London, London, 2005.

[11] Foster, M.V. and Sethares, K.A. "Facilitators and barriers to the adoption of telehealth in older adults: an integrative review." Computers Informatics Nursing 32, 11 (2014), pp. 523-533.

[12] Howlett, J.G., McKelvie, R.S., Costigan, J., et al. "The 2010 Canadian Cardiovascular Society guidelines for the diagnosis and management of heart failure update: Heart failure in ethnic minority populations, heart failure and pregnancy, disease management, and quality improvement/assurance programs." Canadian Journal of Cardiology 26, 4 (2010), pp. 185-202.

[13] Jaana, M. and Paré, G. "Home telemonitoring of patients with diabetes: a systematic assessment of observed effects." Journal of Evaluation in Clinical Practice 13, 2 (2007), pp. 242-253. 


\section{Proceedings of the $50^{\text {th }}$ Hawaii International Conference on System Sciences - 2017}

[14] Jaana, M., Paré, G., and Sicotte, C. "Hypertension Home Telemonitoring: Current Evidence and Recommendations for Future Studies." Disease Management \& Health Outcomes 15, 1 (2007), pp. 19-31.

[15] Jaana, M., Paré, G., and Sicotte, C. "Home telemonitoring for respiratory conditions: a systematic review." The American Journal of Managed Care 15, 5 (2009), pp. 313-320.

[16] Jayanti, R.K. and Burns, A.C. "The antecedents of preventive health care behavior: An empirical study." Journal of the Academy of Marketing Science 26, 1 (1998), pp. 6-15. [17] Kitsiou, S., Paré, G., and Jaana, M. "Effects of home telemonitoring interventions on patients with chronic heart failure: an overview of systematic reviews." Journal of Medical Internet Research 17, 3 (2015), pp. e63.

[18] Kotb, A., Cameron, C., Hsieh, S., and Wells, G. "Comparative Effectiveness of Different Forms of Telemedicine for Individuals with Heart Failure (HF): A Systematic Review and Network Meta-Analysis." PLOS ONE 10, 2 (2015), pp. e0118681.

[19] Lainscak, M., Blue, L., Clark, A.L., et al. "Self-care management of heart failure: practical recommendations from the Patient Care Committee of the Heart Failure Association of the European Society of Cardiology." European Journal of Heart Failure 13, 2 (2011), pp. 115-126. [20] Liao, L., Allen, L.A., and Whellan, D.J. "Economic burden of heart failure in the elderly." Pharmacoeconomics 26, 6 (2008), pp. 447-462.

[21] Liou, H.-L., Chen, H.-I., Hsu, S.-C., Lee, S.-C., Chang, C.-J., and $\mathrm{Wu}, \mathrm{M}$.-J. "The effects of a self-care program on patients with heart failure." Journal of the Chinese Medical Association 78, 11 (2015), pp. 648-656.

[22] Louis, A.A., Turner, T., Gretton, M., Baksh, A., and Cleland, J.G. "A systematic review of telemonitoring for the management of heart failure." European Journal of Heart Failure 5, 5 (2003), pp. 583-590.

[23] Martín-Lesende, I., Recalde, E., Viviane-Wunderling, P., et al. "Mortality in a cohort of complex patients with chronic illnesses and multimorbidity: a descriptive longitudinal study." BMC Palliative Care 15, 1 (2016).

[24] Mathieson, K. "Predicting user intentions: comparing the technology acceptance model with the theory of planned behavior." Information systems research 2, 3 (1991), pp. 173-191.

[25] McMurray, J.J.V., Adamopoulos, S., Anker, S.D., et al. "ESC Guidelines for the diagnosis and treatment of acute and chronic heart failure 2012: The Task Force for the Diagnosis and Treatment of Acute and Chronic Heart Failure 2012 of the European Society of Cardiology. Developed in collaboration with the Heart Failure Association (HFA) of the ESC." European Heart Journal 33, 14 (2012), pp. 1787 1847.

[26] ORCA. "Senior Living Options." ORCA Ontario Retirement Communities Association, 2013. http://www.orcaretirement.com/retirement-living/seniorsliving-options/.

[27] Paré, G. and Elam, J.J. "Discretionary use of personal computers by knowledge workers: testing of a social psychology theoretical model." Behaviour \& Information Technology 14, 4 (1995), pp. 215-228.
[28] Paré, G., Jaana, M., and Sicotte, C. "Systematic Review of Home Telemonitoring for Chronic Diseases: The Evidence Base." Journal of the American Medical Informatics Association 14, 3 (2007), pp. 269-277.

[29] Paré, G., Moqadem, K., Pineau, G., and St-Hilaire, C. "Clinical Effects of Home Telemonitoring in the Context of Diabetes, Asthma, Heart Failure and Hypertension: A Systematic Review." Journal of Medical Internet Research 12, 2 (2010), pp. e21.

[30] Peeters, J.M., de Veer, A.J., van der Hoek, L., and Francke, A.L. "Factors influencing the adoption of home telecare by elderly or chronically ill people: a national survey." Journal of clinical nursing 21, 21-22 (2012), pp. 3183-3193.

[31] Radhakrishnan, K. and Jacelon, C. "Impact of telehealth on patient self-management of heart failure: a review of literature." Journal of Cardiovascular Nursing 27, 1 (2012), pp. 33-43.

[32] Riegel, B., Carlson, B., Moser, D.K., Sebern, M., Hicks, F.D., and Roland, V. "Psychometric testing of the self-care of heart failure index." Journal of cardiac failure 10, 4 (2004), pp. 350-360.

[33] Riley, J.P., Gabe, J.P., and Cowie, M.R. "Does telemonitoring in heart failure empower patients for selfcare? A qualitative study." Journal of Clinical Nursing 22, 17-18 (2013), pp. 2444-2455.

[34] Sun, Y., Wang, N., Guo, X., and Peng, Z. "Understanding the acceptance of mobile health services: a comparison and integration of alternative models." Journal of Electronic Commerce Research 14, 2 (2013), pp. 183.

[35] United Nations. "World population ageing 2015." Department of Economic and Social Affairs Population Division, (2015).

[36] Van Offenbeek, M., Boonstra, A., and Seo, D. "Towards integrating acceptance and resistance research: evidence from a telecare case study." European Journal of Information Systems 22, 4 (2013), pp. 434-454.

[37] de Veer, A.J., Peeters, J.M., Brabers, A.E., Schellevis, F.G., Rademakers, J.J.J., and Francke, A.L. "Determinants of the intention to use e-Health by community dwelling older people." BMC health services research 15, 1 (2015), pp. 103. [38] Venkatesh, V. and Davis, F.D. "A theoretical extension of the technology acceptance model: Four longitudinal field studies." Management science 46, 2 (2000), pp. 186-204.

[39] Venkatesh, V., Morris, M.G., Davis, G.B., and Davis, F.D. "User acceptance of information technology: Toward a unified view." MIS quarterly, (2003), pp. 425-478.

[40] Ware Jr, J.E., Kosinski, M., and Keller, S.D. “A 12-Item Short-Form Health Survey: construction of scales and preliminary tests of reliability and validity." Medical care 34, 3 (1996), pp. 220-233.

[41] WHO Media centre. The top 10 causes of death. Fact sheet 310 [updated May 2014]. World Health Organization, Geneva, 2015.

[42] World Health Organization and Public Health Agency of Canada. Preventing chronic diseases: a vital investment. World Health Organization; Public Health Agency of Canada, Geneva; Ottawa, 2005.

[43] Zavertnik, J.E. "Self-care in older adults with heart failure: an integrative review." Clinical Nurse Specialist 28, 1 (2014), pp. 19-32. 